\title{
MUCOSAL HISTOLOGY FOLLOWING PROLONGED USE OF THE UROVAC: A SUCTION OPERATED URINAL
}

\author{
By F. X. KeAne, M.B., M.R.C.P.I., M.F.O.M. \\ Spinal Unit, National Medical Rehabilitation Centre, Dun Laoghaire, \\ Co. Dublin, Ireland.
}

\begin{abstract}
Biopsies were taken from the medial surface of the labia minora at 6 monthly intervals in the case of a young adult paraplegic using a suction operated urinal (the Urovac, Keane, 1963). An average partial vacuum of II.4 cm measured by the water gauge was continuously applied to the tissues. There was no effective change in histological appearance of the mucous membrane over a period of 18 months. The tissue showed some irregular thickening of the squamous mucosa and moderate parakeratosis. There was a mild fibroblastic and papillary proliferation in the submucosa with occasional small aggregates of polymorphonuclear leucocytes immediately underlying the mucosa. These changes are non-specific and indicative of mild irritation. It would appear therefore that it is safe to apply a partial vacuum of $1 \mathrm{I} \cdot 4 \mathrm{~cm}$ to the mucous membrane for prolonged periods provided that tissue distention is prevented by urinal design.
\end{abstract}

Key words: Histopathology; Urinal; Incontinence.

\section{Introduction}

I AM not aware that any worker has reported the effects of prolonged use of a suction operated female urinal. There is the obvious danger of producing tissue damage due to the application of even a low partial vacuum to soft tissue. The object of this short paper is to report the histology of biopsies taken from the inner surface of the labia minora of a young adult paraplegic who used a suction operated urinal (Urovac, Keane, I963), for a prolonged period.

The amputee using a suction socket demonstrates that exposure of skin to a low partial vacuum will produce oedema and a condition which resembles venous obstruction with eventual ulceration. The introduction of what is now known as 'The American Total Contact Quadrilateral Socket' is potentially a suction socket but provides total contact between the skin and socket preventing tissue distention. This socket produces no pathology and in fact is an effective treatment for stumps ulcerated by a suction socket. The design of a suction-operated urinal therefore required, on the one hand, total tissue contact and on the other, the ability to lift or suck urine and other secretions off the mucosa when these are interposed between the suction head and tissue surface. It is obvious therefore that a compromise between total tissue support and porosity must be reached in the design of a suction operated urinal.

\section{The Urovac}

The Urovac has been described (Keane, 1963). In brief, it consisted basically of a suction head, cast in a semi-rigid plastic, and contoured for application to the external genitalia. A multiplicity of small ducts ( $1.5 \mathrm{~mm}$ diameter), led from the applied surface in contact with the vestibule of the vagina, urethral orifice, the vaginal opening, the vestibular fossa, the posterior commissure and the medial 
surfaces of the labia minora or majora to a central chamber in the body of the device. This chamber was connected by a length of suction tubing to a urine container from which air was exhausted by a continuously running vacuum pump. This pump was of a centrifugal vein type so that a suction of no more than $30^{\prime \prime}$ water gauge vacuum could be reached at any time, whether properly maintained or not. The pump was capable of drawing 3 cubic feet of free flow air per minute through the system. A $\frac{1}{4}$ " thick layer of open cell foam plastic was placed over the suction head before application of the Urovac in correct anatomical position.

The purpose of the foam plastic layer was: (I) to support the mucosa and skin against distention due to the partial vacuum which was maintained at a level of between 3 and 6 inches measured by the water gauge, (2) by expansion to increase porosity to allow voided urine to enter the ducts of the suction head, (3) to meter air entering around the urinal to limit suction to an average level of $4 \frac{1}{2}$ " water gauge and (4) to dry the skin around the periphery of the urinal by permitting air flow through its open cell structure.

\section{Methods}

When the Urovac was first introduced the device was removed at 2-hourly intervals for visual inspection of the genitalia, and the period of use extended with examination morning and evening. Patients were, if possible, trained to use a mirror for personal inspection. In all, only 29 patients were fitted with the Urovac as originally designed. (The device never came into commercial production as each patient required a certain amount of individual fitting and the urinal was not a disposable type.) Many of these used the device successfully over a period of years. None demonstrated any visual change in mucosa or skin as a result of the continuous application of suction at this low level. One problem with the Urovac however, was the drying of secretions in the foam plastic due to the continuous airflow. This arose in patients where urine was only passed a couple of times throughout the night. It resulted in the foam plastic adhering to the mucosa. If

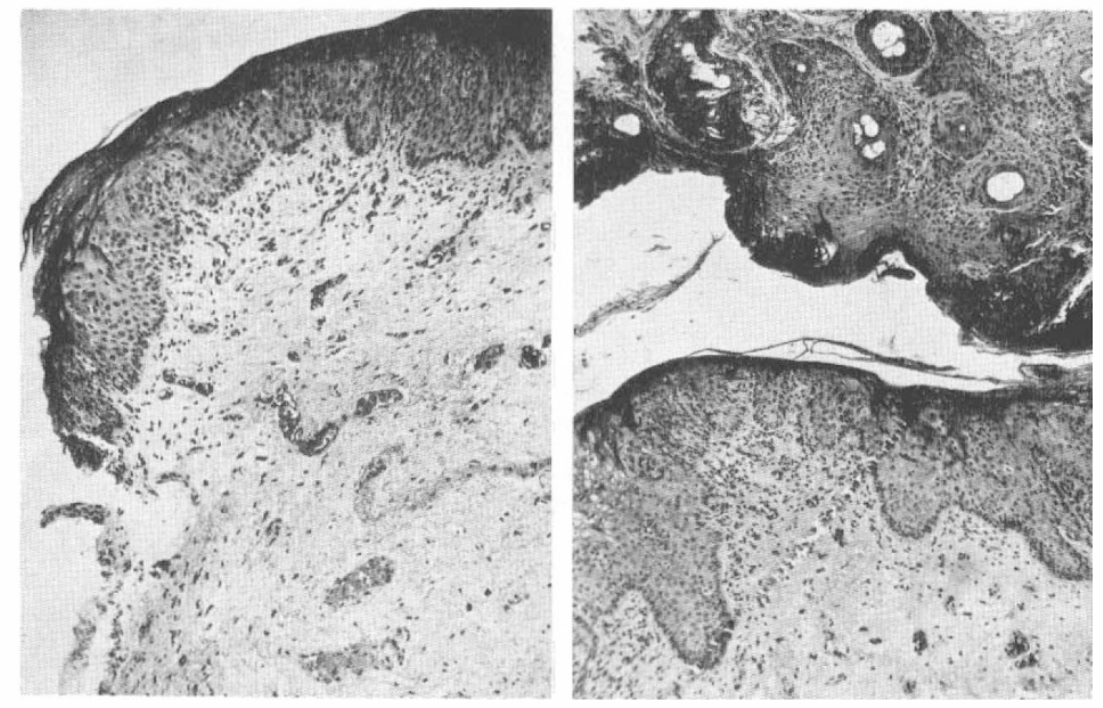

FIG. I

Biopsy from the labia minora after use of Urovac for 12 and 18 months. 
the adherent foam layer was simply pulled off without first soaking with soap and water ulceration of the mucosa resulted.

The case reported in this paper was the first individual fitted with a Urovac. She was a S.R.N. of 35 years of age with a complete traumatic paraplegia below C7. This patient had biopsies taken from the medial aspect of the labia minora after 6, I2 and I 8 months nocturnal use of the Urovac. Fig. I shows the histological appearance after 12 and 18 months respectively. There was no effective change in the tissue in the three biopsies. The tissue showed some irregular thickening of the squamous mucosa and moderate parakeratosis. There was a mild fibroblastic and papillary proliferation in the submucosa with occasional small aggregates of polymorphonuclear leucocytes immediately underlying the mucosa. These changes are non-specific and indicative of mild irritation. The patient in question wore the Urovac for I I years without macroscopic change of the mucosa. Use of the device was discontinued due to the inability to obtain spare parts. It would appear therefore that it is safe to apply a partial vacuum of I I. $4 \mathrm{~cm} \mathrm{W.G.} \mathrm{to} \mathrm{the} \mathrm{mucosa} \mathrm{for} \mathrm{proionged} \mathrm{periods} \mathrm{provided} \mathrm{tissue} \mathrm{distention} \mathrm{is}$ prevented by a total contact or tissue supporting urinal.

\section{RÉSUMÉ}

Des biopsies ont été effectuées à partir de la surface médiane des petites lèvres à six mois d'intervalle dans le cas de jeunes adultes paraplégiques, au moyen d'un urinoir à suction Urovac (Keane, I963). Un vaccum moyen partiel de II $4 \mathrm{cms}$, mesuré au moyen d'un indicateur d'eau a été appliqué en permanence sur les tissus. Aucun changement ne s'est révélé dans l'apparence histologique de la muqueuse au cours d'une période de 18 mois. Le tissus a révélé un épaississement irrégulier de la muqueuse squameuse et une parakératose modérée. Une proliferation légère fibroplastique et papillaire est apparue dans la sous muqueuse accompagnée de rares leucocytes polynucléaires juste sous la muqueuse. Il semble donc que l'on peut sans danger appliquer un vide partiel de II.4 cms sur la muqueuse pendant de longues périodes si la conception de l'urinoir permet d'éviter une distension des tissus.

\section{ZUSAMMENFASSUNG}

Biopsien wurden alle 6 Monate von der mittleren Oberflache der labia minora einer jungen, erwachsenen Querschnittsgelähmten durch Gebrauch einer Saugurinflasche genommen: der Urovac (Keane, I963). Das Gewebe wurde konstant einem durchschnittlichen Teilvakuum von II,4 cm auf dem Unterdruckmesser ausgesetzt. Es gab über I8 Monate keine wesentliche Veränderung der histologischen Erscheinung der Schleimhaut. Das Gewebe wies eine etwas unregelmäßige Anschwellung der schuppenförmigen Schleimhäute und mäßige Parakeratose auf. Es gab ein mäßiges Wuchern des Bindgewebes und ein papiläres Wuchern in den Unterschleimhäuten; kleine Aggregate von PolymorphKern-Leukozyten lagen direkt unter den Schleimhäuten. Diese Veranderungen sind nicht spezifisch und weisen auf eine leichte Reizung hin. Es scheint also, daß es ungefährlich ist, die Schleimhaut einem Teilvakuum von I I, $4 \mathrm{~cm}$ über einen langeren Zeitraum auszusetzen, unter der Bedingung, daß eine Gewebeanschwellung durch die Konstruktion der Urinflasche verhindert wird.

\section{REFERENCE}

KEANE, F. X. (1963). A new appliance for incontinent females ("The Urovac"). Fournal of the Irish Medical Association, 3, 5567, 73 I-733. 